\title{
Challenges and opportunities of area-based conservation in reaching biodiversity and sustainability goals
}

\author{
Samuel Hoffmann ${ }^{1}$ (iD
}

Received: 14 August 2021 / Revised: 15 November 2021 / Accepted: 24 November 2021 /

Published online: 1 December 2021

(C) The Author(s) 2021

\begin{abstract}
Area-based conservation is essential to safeguard nature's diversity. In view of expanding human land use, increasing climate change and unmet conservation targets, area-based conservation requires efficiency and effectiveness more than ever. In this review, I identify and relate pressing challenges to promising opportunities for effective and efficient protected area governance and management, to enhance research, decision-making and capacity building in area-based conservation under uncertain future developments. I reveal that protected area management is particularly challenged by human land use, climate change, invasive species, and social, political and economic limitations. Protected area management often lacks the continuous availability of data on current states and trends of nature and threats. Biocultural conservation, climate-smart management and biosecurity approaches help to overcome challenges induced by human needs, climate change and invasive species, respectively. Economic valuation and shifts in funding priorities can boost protected area effectiveness and efficiency. In-situ monitoring techniques, remote sensing and open data infrastructures can fill data and information gaps for protected area planning and management. Moreover, adaptive management is an auspicious concept in the framework of systematic conservation planning to ensure the enduring effectiveness of protected areas despite unpredictable future developments. Post-2020 international biodiversity and sustainable development goals could be met earlier if protected areas were more effective. I consequently conclude with the need for a global information system that is to support area-based conservation by synthesizing challenges and opportunities for protected area management effectiveness and efficiency at the local to global level.
\end{abstract}

Keywords Protected area $\cdot$ Management effectiveness $\cdot$ Adaptive management $\cdot$ Systematic conservation planning $\cdot$ Biodiversity targets $\cdot$ Sustainable development goals

Communicated by Dirk Sven Schmeller.

Samuel Hoffmann

samuel.hoffmann@uni-bayreuth.de

1 Department of Biogeography, University of Bayreuth, Universitaetsstr. 30, 95447 Bayreuth, Germany 


\section{Introduction}

Area-based conservation offers key perspectives to reach post-2020 global biodiversity and sustainability targets (Bhola et al. 2021). Area-based conservation comprises protected areas and other effective area-based conservation measures (OECM). A protected area is a 'clearly defined geographical space, recognized, dedicated and managed, through legal or other effective means, to achieve the long term conservation of nature with associated ecosystem services and cultural values" (Dudley 2008). An OECM is a 'geographically defined area other than a protected area, which is governed and managed in ways that achieve positive and sustained long-term outcomes for the in situ conservation of biodiversity, with associated ecosystem functions and services and, where applicable, cultural, spiritual, socioeconomic, and other locally relevant values' (IUCN WCPA 2019). The distinction between protected areas and OECMs is thereby not obvious. Both protected areas and OECMs imply land or sea that is protected by legal or other means. Examples for OECMs are areas managed by private initiatives, local communities or indigenous people, or water reserves. According to Maxwell et al. (2020), protected areas are primarily for conservation, whereas in OECMs conservation is a secondary effect. This might be the reason why conservation science and practice discovered the value of OECMs only recently (Dudley et al. 2018), while protected areas have always been considered jewels in the crown of conservation (Watson et al. 2014). In this review, I consequently focus on protected areas although findings could be applied to OECMs as well.

Both protected areas and OECMs are principal components of the Convention on Biological Diversity (CBD) 2050 Vision for Biodiversity "Living in harmony with nature", i.e. Aichi Biodiversity Target 11 (CBD 2021), and the United Nations 2030 Agenda for Sustainable Development, i.e., the Sustainable Development Goals (SDGs) 14 'Life below Water' and 15 'Life on Land' (United Nations 2015). Especially, meeting Aichi Target 11 requires that 'at least 17 per cent of terrestrial and inland water areas and 10 per cent of coastal and marine areas, especially areas of particular importance for biodiversity and ecosystem services, are conserved through effectively and equitably managed, ecologically representative and well-connected systems of protected areas and OECMs, and integrated into the wider landscape and seascape'. However, the increasing extent of the global protected area estate is not necessarily an indicator for either effective or efficient conservation (Visconti et al. 2019; Geldmann et al. 2019). The global protected area coverage is growing, but biodiversity is still declining (Watson et al. 2014). One reason for this is the bias of protected area coverage towards remote and residual places with low biodiversity (Joppa and Pfaff 2009) minimizing costs and conflicts with extractive uses (Vieira et al. 2019). However, the discrepancy mentioned has also led to the development of measurements for protected area management effectiveness, i.e. the degree to which conservation targets are met by protected area management (Hockings et al. 2006). Management efficiency reflects the ratio between the management result and the management effort to reach the result. Measuring management effectiveness and efficiency are important constituents of adaptive management within the concept of systematic conservation planning (Sarkar and Illoldi-Rangel 2010). The assessment of management effectiveness requires conservation goals, but not all protected areas aim at measurable conservation targets, e.g. protected areas that enable nature to develop without human land use. For those protected areas, management effectiveness needs to be assessed in different ways, such as by assessing the degree of 
human disturbances inside the protected area. Given that conservation targets need to be quantifiable, estimating management effectiveness also requires monitoring data from protected areas.

Even the most influential conservation goals can be heavily criticized as a recent debate about Aichi Target 11 discloses (Visconti et al. 2019). This controversy revolves around arguments for and against setting protected area coverage as a conservation target. Protected area coverage is a measure easy to apply and to understand for policy-makers but does not account for biodiversity, ecosystem services and social equity within and around protected areas, nor for the connectivity between them. Therefore, management and governance effectiveness needs to be considered in the context of conservation targets at all times.

Methods to evaluate management effectiveness are manifold due to the diversity of protected area designations, their management and conservation targets (Leverington et al. 2010; Rodrigues and Cazalis 2020). The IUCN World Commission for Protected Areas established a renowned approach in which management evaluation includes the definition of evaluable conservation goals, the estimation of applied resources, the selection of target indicators, the measurement of those indicators, and the analysis, interpretation and communication of results (Hockings et al. 2006). Such a standardized method is essential to monitor and improve management effectiveness over time.

Several databases were launched to assess protected area management effectiveness. The World Database on Protected Areas (WDPA) is the foundation for most of them by storing basic spatial and attribute data of protected areas (IUCN and UNEP-WCMC 2021). The Digital Observatory of Protected Areas (DOPA) is a web based information system developed by the European Commission's Joint Research Centre (JRC 2021) that monitors and reports the state of and the pressures on protected areas by using global reference data sets, which reflect a multitude of indicators at country, ecoregion and protected area level. These indicators measure progress towards Aichi Target 11, and SDG 14 and 15. The Global Database on Protected Area Management Effectiveness (GD-PAME) (Coad et al. 2015) reveals that only $21 \%$ of the countries reach the management effectiveness target, which is to evaluate at least $60 \%$ of their national protected area coverage. The management effectiveness tracking tool (METT) is related to PAME and records the quality of protected area management over time (Mascia et al. 2014). The PAME metrics are, however, criticized for insufficiently considering biodiversity outcomes (Visconti et al. 2019). Another civil society's effort to monitor legal changes to protected areas is the Protected Area Downgrading, Downsizing, and Degazettement Tracker (PADDDtracker.org) (Kroner et al. 2019). Furthermore, the Conservation Evidence is a promising initiative to summarise documented evidence for the effectiveness of conservation action (Conservation Evidence 2020).

These databases can be used to demonstrate protected areas' effectiveness in conserving biodiversity. Protected areas can decrease habitat degradation and maintain biodiversity better than other conservation measures (Geldmann et al. 2013). At the local extent, biodiversity can be higher inside protected areas than in their surroundings (Gray et al. 2016). Consequently, protected areas are able to decelerate the decline of biodiversity, even though they cannot halt the loss completely (Geldmann et al. 2019). Protected areas can be especially effective for biodiversity conservation if they are located in biodiversity hotspots (Joppa et al. 2013), actively managed and well-funded (Geldmann et al. 2018). Protected areas can remain effective in preserving species despite climate change (Lehikoinen et al. 2019). In addition, protected areas can effectively provide ecosystem services, e.g. climate regulation (Soares-Filho et al. 2010), natural catastrophe control and the provision 
of habitat and natural resources (Xu et al. 2017), tourism and recreation (Balmford et al. 2009) and poverty reduction (Andam et al. 2010). Protected areas that show no positive difference compared to their surroundings, miss their conservation targets completely, or undergo habitat degradation are called 'paper parks' (Joppa et al. 2008).

Here, I sought to stimulate research, decision-making and capacity building in areabased conservation under uncertain future developments. Hence, I identify and relate knowledge on critical challenges and auspicious opportunities for protected area management effectiveness in the face of global change. I conclude with the proposal for a global information system that synthesizes challenges and opportunities for area-based conservation. Databases and digital observatories such as the WDPA, DOPA, GD-PAME and PADDD Tracker can be the foundation for such a global information system that is to support area-based conservation in reaching the post-2020 biodiversity and sustainability targets at the local to global level.

\section{Challenges of area-based conservation}

\section{Human land use}

Human land use is the main threat to biodiversity (Tilman et al. 2017). About $75 \%$ of the terrestrial habitats have been significantly modified or destroyed by humans (Díaz et al. 2019). Anthropogenic land use impacts on threatened terrestrial vertebrates occur worldwide (Allan et al. 2019). Crop and livestock production are the main reasons for losing habitat (Sanderson et al. 2002), followed by commercial developments, water projects, recreational activities, environmental pollution, human infrastructure, anthropogenic disruption of fire ecology and logging (Stein et al. 2000; Wilcove and Master 2005). The loss of tropical forests and wetlands is particularly alarming because they are extremely rich in biodiversity and act as carbon dioxide sinks counteracting global warming. Protecting 50\% of the Earth's land surface could prevent further biodiversity loss, $\mathrm{CO} 2$ emissions from land conversion, and increase natural carbon removal (Dinerstein et al. 2020). Protecting remaining wilderness areas could reduce the extinction rate of terrestrial biodiversity by 50\% (Di Marco et al. 2019). However, for the preservation of some taxa, protecting less than 50\% of the Earth's terrestrial surface is sufficient (Pimm et al. 2018); for instance, $85 \%$ of plant taxa occur in circa one-third of terrestrial land.

Anthropogenic habitat loss is lower in protected areas, especially in those managed by local communities and indigenous people (Díaz et al. 2019). Indigenous people manage at least $25 \%$ of the global land. This area includes over one-third of the world's protected areas, as well as many other remote and unprotected regions of low human footprints. Protected areas contain the last remaining habitats of many species (Jackson and Gaston 2008). However, anthropogenic land use is expected to expand into protected areas due to increasing human demand for resources (Geldmann et al. 2019). The human pressures on protected areas are increasing and expansions of human land use and protected areas often conflict (Montesino Pouzols et al. 2014; Jones et al. 2018). Approximately one-third of the global protected area estate is already under intense human pressure (Jones et al. 2018).

Human land use does not only induce habitat loss and degradation but also fragmentation. Habitat fragmentation means habitat is reduced in size and divided into fragments, e.g. by transportation infrastructure. Fragments are isolated from each other due to degraded habitat in-between. Habitat fragments are like habitat islands surrounded by 
human-dominated landscapes. Globally, about $90 \%$ of protected areas can be perceived as habitat islands as they are not connected via intact land (Ward et al. 2020). Habitat fragmentation limits movement, dispersal and colonization of species, restricts species' access to resources, reduces population sizes, and supports species invasion through disturbed habitat (Gibson et al. 2013; Fahrig 2017; Tucker et al. 2018). Habitat edges are at higher risks of threats such as wind throw or invasion (Murcia 1995; Porensky and Young 2013). Many of these fragmentation impacts on biodiversity are indirect (Wilson et al. 2016). Fragmentation is expected to proliferate in the future as about 25 million $\mathrm{km}$ of new paved roads are foreseen globally by 2050 (IPBES 2019). In contrast, some species depend on small and isolated habitat patches (Wintle et al. 2019).

Human land use inside protected areas has increased worldwide (Geldmann et al. 2019) but anthropogenic activities are typically less inside larger protected areas (Wiersma et al. 2004). Hunting, recreation and anthropogenic modifications of the fire regime are threats to protected area effectiveness (Schulze et al. 2018). Such activities also induce habitat fragmentation, which prevents biotic dispersal, increases extinction threat and supports invasive species (Wilson et al. 2016). However, a high degree of biodiversity can also depend on human intervention. A classic example for this is the dependence of grassland diversity on mowing (Jacquemyn et al. 2011). Vice versa, there are many people that depend on biodiversity and associated values of nature (Cardinale et al. 2012). It can consequently be sensible to integrate human activities into protected area management. However, such management activities can also significantly alter ecosystems. When top predators are controlled to increase game species, game population can dramatically increase resulting in overgrazing and habitat degradation (Primack and Sher 2016). The extraction of dead wood leads to the removal of resources for many species, which eventually reduces ecosystem functioning (Keeton et al. 2007). The active suppression of natural fires changes ecosystems fundamentally (Nimmo et al. 2013). Fire-dependent species disappear and unintentional wildfires can then become more intensive due to an increased fuel-load. Furthermore, illegal deforestation can foster local climatic changes (Silvério et al. 2015).

\section{Climate change}

Anthropogenic climate change is an unavoidable future challenge for protected areas worldwide. Climate change induces uncertainty in protected area management and planning. Protected areas are exposed to climate change effects, such as rising temperatures, melting of snow and ice, more severe droughts and storms, seasonal shifts, rising sea level and increased environmental acidification (Gross et al. 2017). Climate change impacts may have already affected protected areas to a degree that makes it impossible to achieve their conservation targets (Scheffer et al. 2015). In any case, the risk of protected area downgrading, downsizing and degazettement (PADDD) will grow if protected areas lose the conservation values they were intended to protect (Thomas and Gillingham 2015).

Already in 1985, Peters and Darling warned of the fact that protected areas may lose conservation value if species move out of protected areas due to climate change (Peters and Darling 1985). Climate change can modify habitats inside protected areas in a way that they are no longer suitable for many species (Thomas and Gillingham 2015). Consequently, many species shift their ranges and timing of seasonal behavior, which may disrupt interspecific relationships. However, climate change can also positively affect biodiversity in protected areas. For example, in the Kruger National Park, the population size of elephants is predicted to grow under climate change due to increasing plant productivity (Scheiter 
and Higgins 2012). Such positive effects must be considered by the protected area management as well, because the capacities of protected areas to maintain growing populations are limited. Species occurring within protected areas covering large elevational and latitudinal gradients are likely to find suitable habitat within the same protected areas under climate change (Thomas and Gillingham 2015). Protected areas at high northern latitudes are predicted to become refugia for species migrating polewards under climate change (Berteaux et al. 2018). Nevertheless, the predicted climate-induced redistribution of biodiversity suggests that many protected areas will not retain their current biodiversity (Holsinger et al. 2019). Biodiversity loss within protected areas is rarely compensated for by incoming biota (Fuentes-Castillo et al. 2019).

Global-scale studies on the climate change impact on protected areas revealed that PAs in the temperate and northern high-latitude biomes will likely experience largest shifts of climatic zones by the year 2070 (Hoffmann et al. 2019a), while the magnitude of climate change at a given location, the so-called local climate anomaly, is predicted to be highest inside PAs of the tropical, subtropical and polar countries (Hoffmann and Beierkuhnlein 2020). Both studies suggest that PAs at both extremes of gradients are most exposed to climate change; small PAs at low elevation, with low geodiversity, high human pressure and low irreplaceability for threatened species; and large PAs at high elevation, with high geodiversity, low human pressure and high irreplaceability for threatened species.

Climate-induced changes interact with other threats to biodiversity inside protected areas, e.g. habitat degradation and fragmentation, or the spread of invasive species (Schulze et al. 2018). These threats can accumulate (Bowler et al. 2019). Consequently, climate change hinders protected area management effectiveness by modifying and potentially decreasing biodiversity, with cascading effects on ecosystem functioning and services.

\section{Invasive alien species}

The introduction of non-native species to protected areas is enhanced by climate change, human land use, infrastructure, tourisms, habitat modification such as through fire management, and a loss of native populations (Foxcroft et al. 2013). Invasive alien species decrease native species diversity through predation, disease, competition and hybridisation (Clavero and Garciaberthou 2005; Downey and Richardson 2016); and by altering ecosystem structure and functioning (Eldridge et al. 2011). Invasive non-native species can even lower human well-being provided by protected areas (Shackleton et al. 2019). In some cases, non-native species induce a gain of taxonomic, genetic and functional diversity in native communities (Olden et al. 2004). Non-native species can also prevent erosion, and provide nectar and nesting ground (Kendle and Rose 2000; Shackelford et al. 2013). However, in most cases, non-native species cause a loss of biodiversity and ecosystem functioning (Perrings et al. 2005). The impacts of invasive species have already caused substantial economic costs (Diagne et al. 2021). The threats of biological invasions to protected areas are challenging protected area management worldwide (Liu et al. 2020).

\section{Human conflicts}

The establishment of protected areas can conflict with human rights, equity, development needs and poverty reduction, if local people are displaced or their access to natural resources of livelihood is restricted by protected area regulations. Local communities and indigenous people may oppose the protected area concept and management staff, provoking 
conflicts at the expense of achieving conservation goals (Andrade and Rhodes 2012). Topdown approaches have particularly caused negative social impacts on local people, disrupting traditional ways of living (García-Frapolli et al. 2009). For example, local communities burnt $5 \%$ of the Bwindi Impenetrable Forest, Uganda, after it was designated as national park (Hamilton et al. 2000).

To avoid human conflicts, the local political, economic, social and cultural issues should be considered by management plans (Redpath et al. 2013). Protected area management consequently needs to describe, explain and communicate conservation targets and related management implications as well as benefits to local people clearly, which also reveals whether management plans match with conservation targets (Schmidt et al. 2019). However, assessing the social impacts of protected areas is often perceived as hostile to conservation (Brockington et al. 2006). Nevertheless, facing a growing human population and conservation needs alike, conservationists must increasingly guide human interactions with nature in cultural landscapes of which humans are an integral part.

\section{Financial requirements}

Protected area planning and management are not only based on conservation effectiveness but also biased by conservation costs and the demands of stakeholders such as local people, landowners, governments, policymakers, managers, practitioners and scientists (Braunisch et al. 2012). International sustainability agendas have therefore proposed balancing global conservation targets and socio-economic development. However, a lack of spending and information about where funding flows come from are the main factors hindering reaching these goals (Reed et al. 2020).

Although global conservation spending has increased (Waldron et al. 2017), funding from (inter-)national conservation organisations and governmental agencies must still grow to meet global conservation goals (Watson et al. 2014). About US \$3.4 to 4.8 billion are indispensable to improve the IUCN conservation status of all endangered Red List species by one level (McCarthy et al. 2012); the protection and management of areas harbouring those species are estimated to cost about US \$76 billion annually. The World Bank is the largest international donor to protected areas, biodiversity conservation and development initiatives, spending about US \$300 million annually (Hickey and Pimm 2011; Miller 2014). Once the protected area plan is adopted politically, its practical implementation is yet another challenge. The financial requirements of implementing protected area plans are often underestimated (Watson et al. 2016).

The global tropics face particularly high poverty, food insecurity, climate change and biodiversity loss, and experience especially high economic, political and environmental pressures which means that the tropics are among the most pressing regions of the global conservation and development agenda (Barlow et al. 2018). However, in tropical countries, there is a mismatch between funding flows and need of joint conservation and development, with highly biodiverse, low development countries receiving no more funding than other countries (Reed et al. 2020). Reed et al. (2020) conclude that other factors seem to be more influential in funding allocation than biodiversity and human development status. Such factors may be governance stability, socio-political conflicts, inequality, political or military alliances, colonial legacies, or even other conservation targets such as climate change mitigation. Future research is needed that explores how funding is linked to such factors as well as to conservation and development outcomes. 


\section{Insufficient data and monitoring}

Filling conservation knowledge gaps and improving conservation forecasts are persistent scientific challenges. Growing conservation knowledge evolves from increasing quality and quantity of data (Wüest et al. 2019). However, despite an increasing amount of biodiversity data, several shortfalls in biodiversity knowledge remain. Hortal et al. (2015) present seven key knowledge gaps for species taxonomy (Linnean), distribution (Wallacean), abundance (Prestonian), evolutionary patterns (Darwinian), abiotic tolerances (Hutchinsonian), traits (Raunkiæran) and biotic interactions (Eltonian). Relationships between these shortfalls vary with spatial, temporal and taxonomic coverage as well as scale. Taxonomic knowledge gaps (Linnean shortfall) particularly hinder progress on any other shortfall. The Wallacean, Prestonian, and Darwinian shortfalls impede knowledge gain about ecological functioning, i.e. the Raunkiæran, Hutchinsonian, and Eltonian shortfalls. The latter three shortfalls prevent progress on all other shortfalls. Moreover, most big biodiversity data is biased towards readily identifiable and valuable taxa from temperate regions of the northern hemisphere that are easily accessible (Hortal et al. 2015).

Deficits and bias of knowledge about nature's diversity induce uncertainties in conservation planning and management but are especially problematic to conservation because it is challenging to convince citizens and politicians of conservation action and funding via insufficient data. Since conservation funds are needed to collect data, conduct monitoring and fill knowledge gaps, this poses a dilemma. Making conservation data and information publicly available at no costs is a first step to solve this dilemma.

Anthropogenic pressures are quickly altering nature, which requires protected area planning and management to consider up-to-date data on the state of nature and the forces influencing it. Monitoring is needed to measure management progress towards conservation targets (Larson et al. 2013). Some authors argue that national-level monitoring is essential to reach global conservation goals (Collen et al. 2013). However, long-term monitoring of biodiversity is currently rare (Ondei et al. 2018). Monitoring requires technical capacity that is costly. The Global Environmental Facility is one of the largest financial backers of nature conservation but barely supports monitoring programmes (Primack and Sher 2016). Monitoring techniques require both, higher efficiency and funding.

\section{Opportunities of area-based conservation}

\section{Biocultural and people-centered conservation}

The growing ecological knowledge has enabled conservationists to state sophisticated conservation targets, but understanding of how to achieve these goals in complex social-ecological systems is still missing (Margules et al. 2020). Human decision-making and governance determine conservation outcomes. Thus, conflicts will arise if nature conservation contradicts human needs, such as poverty reduction (Minteer and Miller 2011) and subsistence (de Matos-Dias et al. 2020).

In protected area management, two main philosophies can be differentiated, the exclusionary "people-free" protected area approaches and the approaches that integrate biodiversity conservation with local peoples' needs. Ignoring political factors, socio-economic demands and well-being of the people within and adjacent to protected areas can erode 
progress towards biodiversity and sustainability targets. Management approaches are thereby needed that consider human demands and offer solutions to human-induced conservation problems.

Biocultural conservation accounts for cultural diversity and biodiversity alike (Gavin et al. 2018). Co-management (Gavin et al. 2015), integrated conservation development projects (Roe et al. 2013), community-based conservation (Brooks 2017) and protected area management incorporating social equity according to Aichi Target 11 (Zafra-Calvo et al. 2019) are biocultural management approaches that integrate local peoples' needs into protected area management. For instance, De Matos-Dias et al. (2020) developed a method to identify poaching hotspots in protected areas to prevent poaching beyond the limits of food subsistence. Such protected area management allows indigenous communities and local people to sustainably use biodiversity for their livelihoods, which simultaneously supports biodiversity conservation.

People-centered conservation governance is a promising biocultural conservation approach to ensure both ecological and social conservation outcomes in the long term, by applying collaborative relationships, equity, reconciliation and redress in response to injustices, community rights, autonomy and traditional adaptive management for the stewardship of nature (Armitage et al. 2020). Community-centered management is to merge nature conservation with economic development and natural resource rights agendas. In community-managed forests, positive outcomes of community management across all three dimensions are, however, rare (Hajjar et al. 2021). Hajjar et al. (2021) show that environmental conditions, effective tenure rights, national context, user-group characteristics and intervention types are key predictors of joint positive outcomes. Margules et al. (2020) describes five scientific and transdisciplinary practices to build relationships between all stakeholders in landscapes and influence their behavior to integrate conservation and development success.

Hanspach et al. (2020) suggests that biocultural conservation for sustainability has to shift focus "from describing how nature and culture are co-produced to co-producing knowledge for sustainability solutions, and in so doing, better account for questions of power, gender and transformations, which has been largely neglected thus far." The IUCN Green List of Protected and Conserved Areas are a first and global certification programme for protected areas that are effectively managed and fairly governed (IUCN et al. 2019). There is evidence that the inclusion of local stakeholders into protected area management is crucial for successful conservation (Oldekop et al. 2016).

\section{Climate-smart conservation}

The uncertainty in future climate projections limits climate-smart management planning (Michalak et al. 2017). Climate-smart conservation planning and management depend on many factors, e.g. the predicted climate change impacts (Gillson et al. 2013), the predictions' uncertainties (Belote et al. 2018), nature's intactness (Watson et al. 2013), prevailing conservation objectives (Belote et al. 2017), the conservation capacity of the land (Gillson et al. 2013), the management resources available (Wintle et al. 2011) and the risks of management actions (Ando et al. 2018). The recommended management strategies are associated with management interventions that vary from low intensity, e.g. monitoring, to high intensity, e.g. assisted migration and restoration (Gillson et al. 2013). Management practice may thus be conservative, innovative, flexible, reversible or experimental (Belote et al. 2018). In general, each climate-related management guideline aims either at the persistence 
and resistance of biodiversity despite climate change (Lawrence et al. 2021), or at the adaptation of biodiversity to climate change (Gross et al. 2017). The persistence strategy is primarily used for intact ecosystems under low to moderate pressures. If the threat is imminent and conservation objectives are of utmost importance, the resistance strategy can be applied. In the face of rapid climatic changes, the resistance course can be used to save time while preparing strategies to handle the inevitable change of ecosystems. Management strategies that accommodate to unavoidable changes are required for ecosystems that will be heavily and rapidly affected by climate change. 'No-regret' strategies intend to achieve conservation benefits irrespective of climate change (Hallegatte 2009). However, climate-smart management approaches are derived from conservation literature that is biased towards specific species, ecosystems and regions (Felton et al. 2009). Consequently, those climate-wise management recommendations can involve contextual drawbacks. In addition to these climate-smart strategies, protected area management is also expected to mitigate climate change by compensating greenhouse gas emissions, e.g. through forestation (Kintisch 2013).

Ecological restoration is recommended for ecosystems that are characterized by high climate change vulnerability (Gillson et al. 2013) or low conservation value (Belote et al. 2018). Restoration is an intense management intervention to recreate an ecological state prior to degradation (Cairns et al. 2012). Restoration targets include the re-establishment of individual species, communities, ecosystem functions and services or other landscape features. Conservationists apply passive and active restoration. In passive restoration, ecosystems restore without human intervention. In protected areas, restoration increases habitat extent, quality and connectivity (Cairns et al. 2012). Restoration is, however, only meaningful when the threats to restoration targets have been mitigated or removed (Venevsky and Venevskaia 2005). Hence, restoration is difficult under persistent climate change impacts.

A special type of restoration is rewilding. Rewilding is about decreasing human intervention and increasing the self-regulatory ability of ecological and evolutionary processes focusing on the reestablishment of former species assemblages (Svenning et al. 2016). Rewilding can be applied to large extents in contrast to other conservation practices that require intensive human control. Nevertheless, rewilding is also controversial since a lack of control may lead to ecological consequences over large extents that are not intended (Corlett 2016). Because ecological restoration and rewilding cannot compensate for the loss of biodiversity, sustaining pre-existing biodiversity takes priority (Moreno-Mateos et al. 2015). There is, moreover, evidence that restoring degraded habitats is much more expensive than protecting intact habitats (Wilson et al. 2014).

Assisted migration refers to the translocation of species and populations to safeguard those that cannot keep track with climate change velocity (Hendricks et al. 2016). Assisted migration programmes prefer rare and endangered species, but the assisted colonization of pre-adapted ecotypes of keystone species can be more effective for biodiversity conservation in general (Kreyling et al. 2011). Nevertheless, assisted migration between protected areas includes the ecological risks of introducing non-native species (Olden et al. 2011). If assisted migration does not work, ex-situ conservation can be the last chance for some species to persist under climate change.

There is, however, a huge discrepancy between restoration theory and practice (Chazdon et al. 2017). Restoration programs often use top-down approaches and are applied to small scales using methods that are neither cost-effective nor designed to achieve multiple benefits and long-term sustainable outcomes at larger scales (Holl 2017). Ecological restoration requires a more holistic approach considering the local social, cultural and economic 
context, needs and dynamics to achieve multiple benefits at larger scales such as climate mitigation, biodiversity conservation, socio-economic benefits, food security, and ecosystem services (Chazdon and Brancalion 2019). If we consider restoration as a holistic system, this can allocate resources in cost-effective ways. One such approach is to intersect best available spatial information to locate areas where the most beneficial and feasible restoration outcomes overlap (Brancalion et al. 2019).

\section{Biosecurity interventions and surveillance}

The assessment and monitoring of invasion pathways such as through hikers (Hemp 2008), ornamental plantings (Foxcroft et al. 2008) and transported goods are required for effective biosecurity interventions and surveillance (Toral-Granda et al. 2017) and can be very useful to guide effective and efficient management of invasive species (Foxcroft et al. 2019). Transported goods and tourists' equipment could, for instance, be disinfected and planting of non-native species inside protected areas prohibited. Particularly, open remote sensing products and species distribution models help to map and predict the spread of invasive species over large spatial and temporal extents (Devkota et al. 2020).

\section{Economic valuation}

Economic valuation and instruments are helpful to reveal the monetary benefits of protected areas to people. Market-based incentives such as environmental certifications, Payments for Ecosystem Services and multi-lateral approaches such as United Nations Reducing Emissions from Deforestation and Forest Degradation (REDD) are to give decision-makers financial reasons for conservation. For instance, environmentally sustainable products from protected areas can be promoted by organizations and businesses that share their profit with the local producer (Edwards and Laurance 2012).

Financial conservation incentives might especially support developing countries because they contain high biodiversity but tend to societal poverty and injustice, and overconsumption of natural resources for the sake of their development. This is why conservation-oriented organizations and governments financially and technically invest into conservation within developing countries in order to build the countries' self-reliance in the conservation context (Paknia et al. 2015). Many businesses that enter protected areas and harm nature are only profitable due to governmental subsidies such as tax breaks, direct payments, price supports, cheap fossil fuel, road infrastructure and the free provision of common-property resources (Myers 1998). The discontinuation of perverse subsidies to environmentally harmfully businesses is one target of the CBD (Merckx and Pereira 2015).

It is, however, challenging to assess all environmental costs and benefits and incorporate them into cost-benefit analyses and impact assessments. Until now, most economic assessments underestimate nature's values or do not even include the entire range of nature's values such as option or intrinsic values (Maron et al. 2013). Moreover, marketing the natural capital of protected areas can also conflict with conservation. The reason for this is how natural capital is conventionally considered. Natural capital is usually viewed as an input into producing outputs of benefits to people that is not different from any other types of capital. However, natural capital is very different from other forms of capital, if it can be perceived as a type of capital at all. Natural capital holds irreversible, renewable, restorative, biotic and evolving properties; option values for coming generations; and was not made by humans (Mayer 2019). It is therefore risky to apply conventional economic 
approaches to managing natural capital. In contrast to the economic valuation of nature, a purely intrinsic valuation is not compatible with market-based conservation approaches either. This is why Mayer (Mayer 2019) advocates a dual approach of using accounting approaches to maintaining and restoring existing natural assets, and economic valuations to additional natural investments because the dual approach avoids the risks of degrading natural assets inherent in economic valuations and of preventing people from using nature's benefits inherent in accounting approaches. Furthermore, monetary conservation incentives can restrict the traditional use of natural resources, which can modify the human perception of nature's values from subsistence to money related (Chervier et al. 2019). This can cause non-compliance with conservation regulation when payments stop.

\section{Funding}

Protected area management requires financial resources for staff, equipment and infrastructure. Funding from (inter-)national conservation organisations and governmental agencies still needs to increase (Watson et al. 2014), even though conservation funds have significantly grown over the last four decades (Zaradic et al. 2009). The World Bank spends, on average, US \$275 million annually to protect areas in developing countries (Hickey and Pimm 2011). As a comparison, the United States spent threefold the amount for military purposes in 2014 (Primack and Sher 2016). Shifting priorities of large funding bodies to conservation issues would boost conservation effectiveness globally (Rands et al. 2010). Funds can usually produce greatest conservation benefits if they are concurrently spent on management enforcement and protected area expansion (Adams et al. 2019b). Nevertheless, misalignment between funding flows, conservation and development needs is frequently observed, particularly in the tropics, where hotspots of biodiversity meet human pressures and development needs (Reed et al. 2020). Hence, future research is required on how funding is linked to governance stability, socio-political conflicts, inequality, political or military alliances, colonial legacies, or even other conservation targets such as climate change mitigation as well as conservation and development outcomes.

\section{Data and monitoring advances}

A lack of information and knowledge limits effective and efficient conservation. Open access publications, open data and open-source software help to gather and share conservation data and knowledge. Global information systems, data repositories, databases and single data sets play a central role in sharing global conservation data and knowledge. Many such data systems even enable citizen scientists to contribute to data collection, monitoring and analysis, i.e. crowdsourcing (McKinley et al. 2017). Such open-access initiatives can thus foster conservation effectiveness and efficiency.

Times-series data is particularly valuable for conservation planning (García-Barón et al. 2020). Monitoring can be realised by field stations, field surveys and remote sensing techniques, and ideally combinations thereof (Haase et al. 2018). The International Long-Term Ecological Research network (ILTER) is one example of long-term environmental monitoring stations across four continents. Ideally, each protected area would contain such monitoring stations that could be run by protected area staff. To compare results from different localities, such standardized monitoring methodology is needed (Haase et al. 2018).

Remote sensing is a quickly developing method for environmental data collection and monitoring that facilitates time- and cost-efficient biodiversity observations, which is 
particularly important for conservation while nature is rapidly changing (Rocchini et al. 2019). Rose et al. (2015) have identified ten major opportunities on how remote sensing can support conservation, addressing e.g. the monitoring of species distributions, ecosystem functioning and services, land use change, habitat degradation, climate change impacts and management effectiveness. Remote sensing products can also be used to plan protected area networks (Wegmann et al. 2014). Remote sensing data are used to monitor the status of protected areas, such as indicated by vegetation patterns (Hoffmann et al. 2019b), human disturbance and the distribution of native, non-native and migratory species (Gillespie et al. 2015). Since developments outside protected areas affect the interior qualities of protected areas (Hellwig et al. 2019), the surroundings of protected areas should be monitored, too. Such time- and cost-efficient biodiversity assessments support conservation planning and management across large geographical extents, where the collection of field data is not feasible (Devkota et al. 2020). Field observations are, however, inevitable to validate remotely sensed information about biodiversity and the environment (i.e. ground-truthing) (Horning et al. 2010).

If biodiversity is the conservation target, protected area planning and management will have to measure biodiversity. However, measurements mostly focus on biodiversity surrogates at some agreed level such as diversity indices and combinations thereof since it is impossible to assess all dimensions of biodiversity from genetic to ecosystem diversity (Socolar et al. 2016). This might mislead planning and management since species richness changes are uncoupled from changes in other biodiversity metrics (Hillebrand et al. 2018). Once surrogates are chosen, systematic procedures should be applied to assess biodiversity priority areas for conservation. These procedures are predominantly based on the complementarity and irreplaceability of areas but persistence and vulnerability are increasingly addressed under global (climate) change as well (Margules et al. 2002).

The optimisation of sampling techniques is a hot topic in conservation, too (Serra-Diaz and Franklin 2019). Optimisation means collecting more information in a shorter time and at lower costs. The ratio between the amount of information collected and sampling effort (i.e. time and costs) can be increased, particularly in vegetation surveys (Hoffmann et al. 2019c). Opening and communicating this knowledge about optimised field sampling promotes efficient protected area management. Advanced techniques are emerging to record biodiversity data, e.g. artificial intelligence-assisted remote sensing (Horning et al. 2010), automatic species identification (Barré et al. 2017), DNA barcoding (Hebert et al. 2003), compilations of phylogenetic information (Antonelli et al. 2014), non-invasive methods for individual identification, crowdsourcing for species distribution data and sampling approaches for remote and low-technology areas, including traditional knowledge from indigenous communities (Pimm et al. 2015). Species can increasingly be fitted with data loggers that track their movements and activities since these devices shrink in size due to technological advancements (Allen and Singh 2016). Novel assessments of species diversity use acoustic data, e.g. the echolocation calls of bats, occupancy indices and even socio-economic data (Collen et al. 2013). The temporal development of threatened populations and species can, for instance, be reflected by the Red List Index (Butchart, Akcakaya et al., 2006) and the Living Planet Index (WWF, 2018). These indices integrate measures of genetic diversity, population abundance and range size to estimate extinction risk. These indices are used to prioritise species and populations for conservation efforts.

Estimates of biodiversity ignorance within databases will help identify knowledge gaps, design surveys and assess model uncertainties (Hortal et al. 2015). Data bias implies uncertainty in all applications of such data. Uncertainty may prevent decision-makers from acting. Therefore, uncertainty estimates need to be well considered and communicated. 
There are approaches to decision-making in the conservation context that account for model uncertainties (Polasky et al. 2011). Model uncertainties can be minimized by considering past dynamics (Di Marco et al. 2015), sensitivity analysis and null-models (Feeley and Silman 2010), and by using as many relevant hypotheses, data and models as possible (Conroy et al. 2011). Forecasts are improved by refined theories as well as by the consideration of scale-dependency, inadequacies of input data and sensitivity of projections to model structure and parameterisation (Whittaker et al. 2005).

\section{Systematic conservation planning}

Protected areas are the main tool for nature conservation. The global protected area estate has rapidly grown during the last few decades, which has been accompanied by stakeholders that express increasing and more diverse expectations towards protected areas (Watson et al. 2014). Protected areas were originally established to conserve sacred grounds, iconic landscapes, wildlife or natural resources (Ladle et al. 2011). Nowadays they are expected to simultaneously conserve various biotic and abiotic features of nature, ecosystem functions, goods and services, and other human needs. Intact ecosystems inside protected areas deliver services, such as providing carbon storage, drinking water, resilience to natural hazards, and resources for humans and other species to adapt to rapidly changing environments (Naughton-Treves et al. 2005). Trade-offs between contrasting roles are therefore inevitable. The more roles are assigned to protected areas, the more likely protected areas will miss a role. If they are ineffective, protected areas will be prone to degazettement, i.e. to a reduction in size, exploitation or status removal (Mascia and Pailler 2011). There is evidence that protected areas can fulfill multiple roles at the same time (Watson et al. 2014). Due to the ongoing threats to biodiversity and growing human demands, stakeholders will, however, require protected areas to fulfill even more roles simultaneously in the future.

Systematic conservation planning is to design and manage protected areas in a way that they fulfill their roles. The original systematic planning framework postulates a sixstage protocol (Margules and Pressey 2000): (1) compile a solid data basis for the planning region; (2) set conservation targets; (3) review existing protected areas in the region; (4) select additional protected areas; (5) implement conservation action; and (6) maintain conservation values of protected areas. While the original protocol was predominantly considered to locate and design new protected areas, updated frameworks emphasize the adaptive management of established protected areas, i.e. the need to monitor, evaluate, and revise the management of protected areas if management effectiveness or efficiency is lacking. For example, a generically updated protocol by Sarkar and Illoldi-Rangel (2010) incorporates interactions between components and revision and reiteration of planning stages due to feedback between the components. Such adaptive management is particularly necessary when environmental conditions are changing such as under global change.

Conservation prioritisation is-like adaptive management-an integral part of systematic conservation planning (Sarkar and Illoldi-Rangel 2010). To ensure protected area effectiveness and efficiency under limited management resources such as funds and staff, protected area planning and management must be prioritised according to both, conservation targets and threats prevailing (Bonebrake et al. 2019). Araújo et al. (2011), for instance, demonstrates spatial priorities for species conservation by modelling future species distributions under climate change and to what degree predicted distributions overlap with protected areas in Europe. Dobrovolski et al. (2014) show a global prioritisation of 
protected areas that enables sufficient agricultural food production for a growing human population and the conservation of endangered terrestrial mammals. A recent study by Strassburg et al. (2020) prioritises areas for restoration to optimise biodiversity preservation and carbon sequestration worldwide.

The prioritisations and integration of local protected area planning and management into a wider spatial and temporal perspective, and into national and international policies would foster individual protected areas in solving global environmental problems beyond their local conservation benefits (Hoffmann 2021). Protected area networks and international agreements on nature conservation are two examples of large-extent conservation. Protected area networks and protected area connectivity support species migration and metapopulation dynamics, buffering detrimental effects of climate change on biodiversity (Lehikoinen et al. 2019). The establishment of continent-wide protected area networks and migration corridors is therefore essential to safeguard high biodiversity. 'Protected Connected' (ProtConn) is a recently developed global indicator to measure connectivity inside terrestrial protected area systems (Saura et al. 2018). In addition to protected area connectivity, spatially dynamic protected areas could also protect migrating species on their ways (Alagador et al. 2014), even though mobile protected areas are hard to realise in cultural landscapes. New protected areas should be established in places where species will find suitable niches under climate change (Ferreira et al. 2019). A diverse landscape matrix between protected areas generally decreases landscape resistance for species movement and gene flow (Daily et al. 2001), which can be realised by agro-forestry systems, for example (Bhagwat et al. 2008). Furthermore, in the face of continuing threats such as climate change, the temporal perspective of conservation planning needs to be long-term. Accordingly, it is vital to understand past dynamics to predict future developments and thus improve conservation planning and management despite permanent change (Hannah et al. 2002).

\section{Adaptive management}

Since biodiversity and abiotic environments are changing over time, conservation planning and management must become dynamic. Future predictions are to some degree uncertain and uncertainty may prevent decision-makers from acting. A variety of methods can, however, account for model uncertainties (Moilanen et al. 2009). The challenge is consequently to develop systematic conservation planning and management that is robust to uncertainty.

Among several approaches to effective protected area governance and management (Worboys et al. 2015), adaptive management is a key concept to ensure the enduring effectiveness, and also efficiency, of protected areas in the light of uncertain future developments (Allen et al. 2011). Adaptive management is an integral part of modern frameworks of systematic conservation planning (Sarkar and Illoldi-Rangel 2010). The higher the uncertainty is, the higher is the necessity of adaptive management to achieve management effectiveness. The fundamental components of adaptive management are the continual evaluation of management effectiveness and the continual adaptation of management efforts to maintain or increase the management effectiveness. Adaptive management can thus address any management challenge that involves a measurable conservation target, management result and management effort required to reach the result. The iterative approach of adaptive management enables well-grounded decision-making despite uncertainties in the system. Uncertainty is reduced by regular system monitoring that is used to evaluate management effectiveness. Adaptive management thus means continuously learning about a system in 
order to be able to change the system. In this way, adaptive management can improve management effectiveness. If management effectiveness is monitored, and knowledge transfer and adaptation of management are sufficiently funded and realized, the major challenge of adaptive management will be to implement a reasonable balance between long-term and short-term management effectiveness (Williams 2011).

An adaptive management cycle is grounded on principles of systematic conservation planning (Sarkar and Illoldi-Rangel 2010), including adaptive conservation management in the face of environmental changes (Gillson et al. 2019). The scientific foundation of an adaptive management cycle is based on the monitoring and evaluation of management. Monitoring management effectiveness implies up-to-date data on given conservation targets in relation to management action. Monitoring enables the evaluation of management effectiveness. Every evaluation approach is prone to contextual shortcomings, which decrease the credibility and accountability of evaluation results (Adams et al. 2019a): sophisticated evaluation methods have to consider counterfactual thinking and confounding factors. Monitoring and evaluating management effectiveness can also be used to estimate the risk of losing management effectiveness under future scenarios. A lack of monitoring and research makes it difficult to evaluate progress towards management targets, which is particularly challenging under-resourced management.

Recent developments aim at closing the different data and knowledge gaps that result from a lack of monitoring and restricted access to literature and data bases. Long-term and in-situ monitoring programmes, e.g. ILTER, or new developments in remote sensing, e.g. Sentinel missions, can deliver data to observe protected areas almost continuously. Citizen science can complement professional monitoring and research in disciplines where reliable data can be recorded by amateurs (McKinley et al. 2017). Open-access literature, opensource software and open data help to spread information and knowledge.

Conservation management plans will be adjusted in the adaptive cycle if research and monitoring reveal deficits in management effectiveness or efficiency. Alternative management plans are then discussed, prioritised and decided on in a preferably open and democratic debate integrating and consulting stakeholders, such as scientists, managers, governments, policy-makers, non-governmental organisations, local people and the general public. The consideration and prioritisation of ecological, social, legal and economic aspects make adaptive management plans comprehensive and transdisciplinary. This process is a three-level approach moving from management goals to management options and then to management action. However, uncertain future developments may also require revisiting conservation targets. Stakeholders then agree on several management plans tracking different targets that can be followed under alternative future scenarios. Accordingly, emerging management plans can be both, reactive (i.e. responding to impacts already present) and anticipatory (i.e. preparing for future developments). Management plans should thus include a short and long-term perspective.

The implementation of resulting management plans is conducted via funding, legislation, infrastructure, equipment and the engagement of citizens. This adaptive management cycle is closed with the execution of management plans and another cycle starts with monitoring management effectiveness and efficiency.

\section{Towards a global information system for area-based conservation}

Although global conservation efforts are growing, the Aichi Biodiversity Targets were not be met by 2020 (Díaz et al. 2019). Because humans progressively dominate the 
earth's systems, area-based conservation increasingly integrates the human dimension (Ellis 2019), which is also recognized by the SDG 14 and 15. The SDGs generally incorporate human development and nature conservation by addressing poverty, inequality, climate change, environmental degradation, prosperity, peace and justice. The authors of the report from the 7th Intergovernmental Science-Policy Platform on Biodiversity and Ecosystem Services (IPBES) plenary session suggest diverse environmental, economic, societal and political actions that are required to attain these targets (Díaz et al. 2019).

Many of these actions relate to area-based conservation: promoting sustainable resource management, agriculture and fishery; implementing hunting and fishing quotas; applying multifunctional spatial planning; establishing protected areas; reducing habitat fragmentation; reducing poverty and inequality; promoting technology, innovation and investments in conservation; generating and sharing knowledge; and promoting education. In all these examples, capacity building, integrated management and cross-sectoral approaches need to be adopted pre-emptively to account for trade-offs between stakeholders (Díaz et al. 2019). The UNESCO Man and Biosphere Reserves are successful examples of such integrated and transdisciplinary conservation approaches (Dyer and Holland 1988). By merging biodiversity conservation and ecosystem services, protected areas help to reach the biodiversity and sustainable development goals alike (Dinerstein et al. 2019). Unfortunately, the discussion about the effectiveness and efficiency of areabased conservation is less vigorous these days because we could not meet any of the Aichi Targets by 2020 (Díaz et al. 2020).

Area-based conservation can offer solutions to the environmental problems of the Anthropocene and are preferred conservation policies for conservationists given climate change (Hagerman and Satterfield 2014). Aichi Target 11 sets a terrestrial protected area coverage of $17 \%$ as an international conservation target, but protected area extent does not indicate conservation effectiveness (Visconti et al. 2019; Geldmann et al. 2019). For that reason, a certain degree of management effectiveness of the global protected area estate should become a legally binding global target as well. While the global protected area coverage of species and ecosystem diversity is well investigated, a global analysis

Table 1 Challenges and associated opportunities of area-based conservation in reaching biodiversity and sustainability goals

\begin{tabular}{ll}
\hline Challenges & Opportunities \\
\hline Human land use & Biocultural and people-centered conservation \\
Climate change & Climate-smart conservation \\
Invasive alien species & Biosecurity interventions and surveillance \\
Human conflicts & Biocultural and people-centered conservation \\
Financial requirements & $\begin{array}{c}\text { Economic valuation, more funding and shifts in funding } \\
\text { priorities }\end{array}$ \\
Insufficient data and monitoring & In-situ monitoring techniques, remote sensing and open data \\
& infrastructures \\
Multiple simultaneous challenges & Systematic conservation planning and prioritization \\
Uncertain future developments & Adaptive management \\
Information deficit at the local to global level & Global information system \\
\hline
\end{tabular}


of protected areas covering genetic as well as functional diversity, and ecosystem services is still missing, but necessary to report progress towards Aichi Target 11.

As depicted above, there are many individual challenges and opportunities of effective area-based conservation (Table 1). However, a comprehensive analysis that reveals the complex relationships between various conservation targets, threats, challenges and opportunities of effective management across the global protected area estate has not been realised yet. In my opinion, this is a main future, albeit ambitious perspective in conservation. Such a comprehensive and global analysis should be updated frequently with most recent data. A global information system can provide these pieces of information for individual protected areas and protected area networks, to ensure the long-term preservation of nature by protected areas across the globe. It is consequently necessary to establish long-term monitoring of nature, threats and management effectiveness within protected areas all over the world. Artificial intelligence and deep learning are promising computational technologies for nature conservation since they enable an automated classification of big monitoring data (Lamba et al. 2019). Nevertheless, resources for monitoring are limited. Given that, only a selection of variables can be prioritised. Scientists have recently argued for sets of essential variables that reflect states and trends of nature. These essential variables relate to climate (Bojinski et al. 2014), oceans (Constable et al. 2016), biodiversity (Pereira et al. 2013), geodiversity (Schrodt et al. 2019) and progress towards SDGs (Reyers et al. 2017). The definition of essential variables has led to advances in data collection, storage, distribution and use (Kissling et al. 2015) that are essential to big data analyses (Runting et al. 2020). Remote sensing and long-term ecological research stations are sophisticated techniques to monitor essential variables.

Outcomes from such big data analyses can form the scientific foundation of adaptive area-based conservation and other approaches to systematic conservation planning (Fig. 1). There are many examples of adaptive management frameworks for conservation under rapid environmental changes (Rist et al. 2013). For instance, Gillson et al. (2019) developed an advanced adaptive management cycle providing appropriate tools and approaches for integrating multiple forms of evidence to understand and manage complex dynamic systems. Such adaptive management concepts help to model future dynamics of nature for social, political and economic criteria and developments. These frameworks can be applied to individual protected areas and OECMs, or networks. Adaptive management of a network of areas requires cross-scale communication and coordination. Global information systems involving analyses of data from remote and in-situ monitoring can then inform these management regimes, and vice-versa (Fig. 1).

The WDPA, DOPA, GD-PAME and PADDD Tracker could be the base of a global information system for area-based conservation. The DOPA already provides web services and applications that can be used to assess, monitor, report and model the state of and the pressure on protected areas (JRC 2021). Indicators are provided which assess the progress towards meeting Aichi Target 11, and SDG 14 and 15 at country, ecoregion and protected area level. The data, indicators, maps, models and tools from the DOPA can assist protected area managers, policy makers, funding agencies, researchers and the CBD. The DOPA can particularly be of benefit to protected area management and development, resource allocation, and national and international reporting. The DOPA thus supports decision making and capacity building in area-based conservation. I therefore consider the further development and worldwide application of such a global information system as a promising perspective to enhance area-based conservation effectiveness and meet post-2020 biodiversity and sustainability targets from local to global scales. 


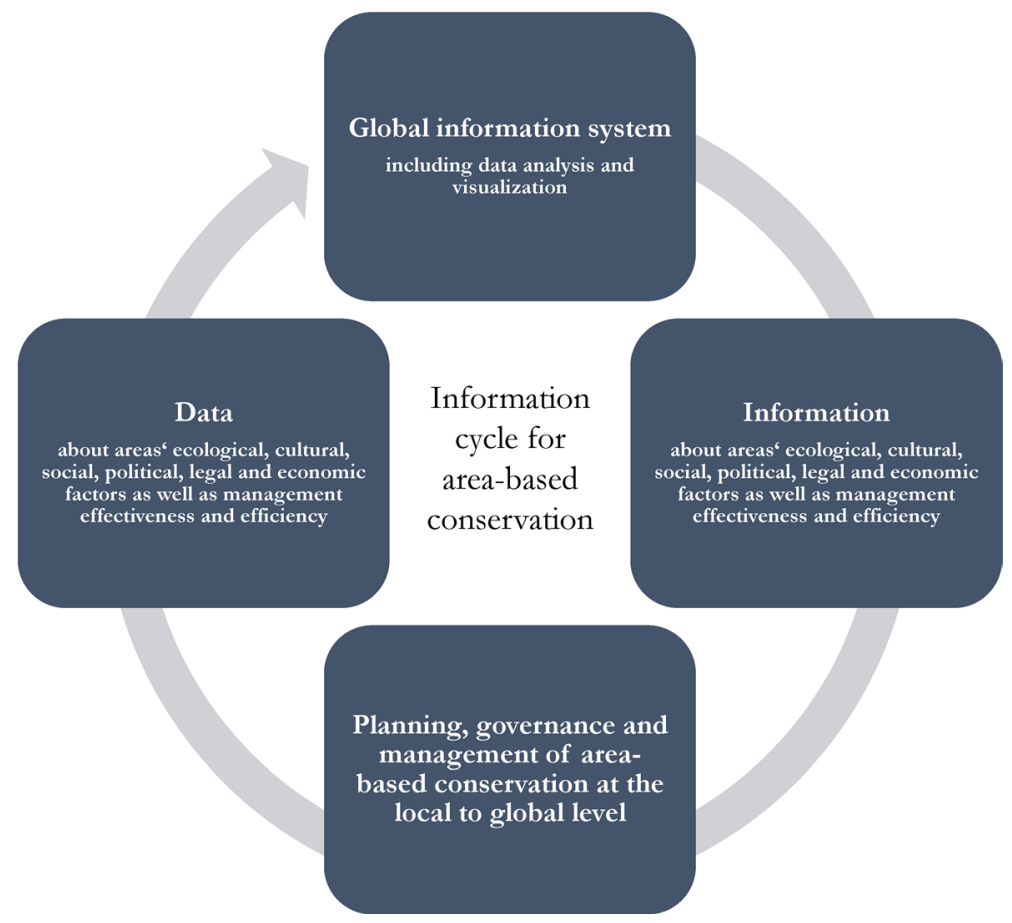

Fig. 1 Information cycle to support area-based conservation worldwide. Global information systems (e.g. DOPA) involving analyses of data from remote and in-situ monitoring provide information about areas' biotic and abiotic environment, and management effectiveness and efficiency. This information can be used for systematic conservation planning including adaptive management of individual protected areas, protected area networks and OECMs. Conservation governance and management is also to provide data about the biotic and abiotic environment, and the management effectiveness and efficiency to the global information system

Acknowledgements I am very grateful to my new-born son Hannes for motivating me to work on a liveable future Earth. I dedicate this paper to him. I am also thankful for the constructive comments of Carl Beierkuhnlein, Ludmila Rattis, and four anonymous reviewers on earlier versions of this manuscript.

Author contributions Not applicable.

Funding Open Access funding enabled and organized by Projekt DEAL. Not applicable.

Data availability Not applicable.

Code availability Not applicable.

\section{Declarations}

Conflict of interest The author declares that he has no competing interest. 
Open Access This article is licensed under a Creative Commons Attribution 4.0 International License, which permits use, sharing, adaptation, distribution and reproduction in any medium or format, as long as you give appropriate credit to the original author(s) and the source, provide a link to the Creative Commons licence, and indicate if changes were made. The images or other third party material in this article are included in the article's Creative Commons licence, unless indicated otherwise in a credit line to the material. If material is not included in the article's Creative Commons licence and your intended use is not permitted by statutory regulation or exceeds the permitted use, you will need to obtain permission directly from the copyright holder. To view a copy of this licence, visit http://creativecommons.org/licenses/by/4.0/.

\section{References}

Adams VM, Barnes M, Pressey RL (2019a) Shortfalls in conservation evidence: moving from ecological effects of interventions to policy evaluation. One Earth 1:62-75. https://doi.org/10.1016/j.oneear. 2019.08.017

Adams VM, Iacona GD, Possingham HP (2019b) Weighing the benefits of expanding protected areas versus managing existing ones. Nat Sustain 2:404-411. https://doi.org/10.1038/s41893-019-0275-5

Alagador D, Cerdeira JO, Araújo MB (2014) Shifting protected areas: scheduling spatial priorities under climate change. J Appl Ecol 51:703-713. https://doi.org/10.1111/1365-2664.12230

Allan JR, Watson JEM, Di Marco M et al (2019) Hotspots of human impact on threatened terrestrial vertebrates. PLoS Biol 17:e3000158. https://doi.org/10.1371/journal.pbio.3000158

Allen AM, Singh NJ (2016) Linking movement ecology with wildlife management and conservation. Front Ecol Evol 3. https://doi.org/10.3389/fevo.2015.00155

Allen CR, Fontaine JJ, Pope KL, Garmestani AS (2011) Adaptive management for a turbulent future. J Environ Manag 92:1339-1345. https://doi.org/10.1016/j.jenvman.2010.11.019

Andam KS, Ferraro PJ, Sims KRE et al (2010) Protected areas reduced poverty in Costa Rica and Thailand. Proc Natl Acad Sci 107:9996-10001. https://doi.org/10.1073/pnas.0914177107

Ando AW, Fraterrigo J, Guntenspergen G et al (2018) When portfolio theory can help environmental investment planning to reduce climate risk to future environmental outcomes-and when it cannot. Conserv Lett 11:e12596. https://doi.org/10.1111/conl.12596

Andrade GSM, Rhodes JR (2012) Protected areas and local communities: an inevitable partnership toward successful conservation strategies? Ecol Soc. https://doi.org/10.5751/ES-05216-170414

Antonelli A, Condamine F, Hettling H et al (2014) SUPERSMART: ecology and evolution in the era of big data. PeerJ Prepr. https://doi.org/10.7287/peerj.preprints.501

Araújo MB, Alagador D, Cabeza M et al (2011) Climate change threatens European conservation areas. Ecol Lett 14:484-492. https://doi.org/10.1111/j.1461-0248.2011.01610.x

Armitage D, Mbatha P, Muhl E et al (2020) Governance principles for community-centered conservation in the post-2020 global biodiversity framework. Conserv Sci Pract. https://doi.org/10.1111/csp2. 160

Balmford A, Beresford J, Green J et al (2009) A global perspective on trends in nature-based tourism. PLoS Biol 7:e1000144. https://doi.org/10.1371/journal.pbio.1000144

Barlow J, França F, Gardner TA et al (2018) The future of hyperdiverse tropical ecosystems. Nature 559:517-526. https://doi.org/10.1038/s41586-018-0301-1

Barré P, Stöver BC, Müller KF, Steinhage V (2017) LeafNet: a computer vision system for automatic plant species identification. Ecol Inform 40:50-56. https://doi.org/10.1016/j.ecoinf.2017.05.005

Belote TR, Dietz MS, McKinley PS et al (2017) Mapping conservation strategies under a changing climate. Bioscience 67:494-497. https://doi.org/10.1093/biosci/bix028

Belote TR, Carroll C, Martinuzzi S et al (2018) Assessing agreement among alternative climate change projections to inform conservation recommendations in the contiguous United States. Sci Rep 8:9441. https://doi.org/10.1038/s41598-018-27721-6

Berteaux D, Ricard M, St-Laurent M-H et al (2018) Northern protected areas will become important refuges for biodiversity tracking suitable climates. Sci Rep 8:4623. https://doi.org/10.1038/ s41598-018-23050-w

Bhagwat SA, Willis KJ, Birks HJB, Whittaker RJ (2008) Agroforestry: a refuge for tropical biodiversity? Trends Ecol Evol 23:261-267. https://doi.org/10.1016/j.tree.2008.01.005

Bhola N, Klimmek H, Kingston N et al (2021) Perspectives on area-based conservation and its meaning for future biodiversity policy. Conserv Biol 35:168-178. https://doi.org/10.1111/cobi.13509 
Bojinski S, Verstraete M, Peterson TC et al (2014) The concept of essential climate variables in support of climate research, applications, and policy. Bull Am Meteorol Soc 95:1431-1443. https://doi.org/10. 1175/BAMS-D-13-00047.1

Bonebrake TC, Guo F, Dingle C et al (2019) Integrating proximal and horizon threats to biodiversity for conservation. Trends Ecol Evol 34:781-788. https://doi.org/10.1016/j.tree.2019.04.001

Bowler DE, Bjorkman AD, Dornelas M et al (2019) Mapping human pressures across the planet uncovers anthropogenic threat complexes. bioRxiv. https://doi.org/10.1101/432880

Brancalion PHS, Niamir A, Broadbent E et al (2019) Global restoration opportunities in tropical rainforest landscapes. Sci Adv. https://doi.org/10.1126/sciadv.aav3223

Braunisch V, Home R, Pellet J, Arlettaz R (2012) Conservation science relevant to action: a research agenda identified and prioritized by practitioners. Biol Conserv 153:201-210. https://doi.org/10.1016/j.biocon.2012.05.007

Brockington D, Igoe J, Schmidt-Soltau K (2006) Conservation, human rights, and poverty reduction. Conserv Biol 20:250-252. https://doi.org/10.1111/j.1523-1739.2006.00335.x

Brooks JS (2017) Design features and project age contribute to joint success in social, ecological, and economic outcomes of community-based conservation projects. Conserv Lett 10:23-32. https://doi.org/ 10.1111/conl.12231

Cairns S, Dudley N, Hall C et al (2012) Ecological restoration for protected areas: principles, guidelines and best practices. IUCN, Gland

Cardinale BJ, Duffy JE, Gonzalez A et al (2012) Biodiversity loss and its impact on humanity. Nature 486:59-67. https://doi.org/10.1038/nature11148

CBD (2021) Aichi biodiversity targets. https://www.cbd.int/sp/targets/default.shtml. Accessed 1 Jul 2021

Chazdon R, Brancalion P (2019) Restoring forests as a means to many ends. Science 365:24-25. https:// doi.org/10.1126/science.aax9539

Chazdon RL, Brancalion PHS, Lamb D et al (2017) A policy-driven knowledge agenda for global forest and landscape restoration. Conserv Lett 10:125-132. https://doi.org/10.1111/conl.12220

Chervier C, Le Velly G, Ezzine-de-Blas D (2019) When the implementation of payments for biodiversity conservation leads to motivation crowding-out: a case study from the cardamoms forests, Cambodia. Ecol Econ 156:499-510. https://doi.org/10.1016/j.ecolecon.2017.03.018

Clavero M, Garciaberthou E (2005) Invasive species are a leading cause of animal extinctions. Trends Ecol Evol 20:110-110. https://doi.org/10.1016/j.tree.2005.01.003

Coad L, Leverington F, Knights K et al (2015) Measuring impact of protected area management interventions: current and future use of the global database of protected area management effectiveness. Philos Trans R Soc B Biol Sci 370:20140281. https://doi.org/10.1098/rstb.2014.0281

Collen B, Pettorelli N, Baillie JEM, Durant SM (2013) Biodiversity monitoring and conservation. Wiley-Blackwell, Oxford

Conroy MJ, Runge MC, Nichols JD et al (2011) Conservation in the face of climate change: the roles of alternative models, monitoring, and adaptation in confronting and reducing uncertainty. Biol Conserv 144:1204-1213. https://doi.org/10.1016/j.biocon.2010.10.019

Conservation Evidence (2020) Conservation Evidence. https://www.conservationevidence.com/. Accessed 4 Dec 2020

Constable AJ, Costa DP, Schofield O et al (2016) Developing priority variables ("ecosystem Essential Ocean Variables"-eEOVs) for observing dynamics and change in Southern Ocean ecosystems. J Mar Syst 161:26-41. https://doi.org/10.1016/j.jmarsys.2016.05.003

Corlett RT (2016) Restoration, reintroduction, and rewilding in a changing world. Trends Ecol Evol 31:453-462. https://doi.org/10.1016/j.tree.2016.02.017

Daily GC, Ehrlich PR, Sánchez-Azofeifa GA (2001) Countryside biogeography: use of human-dominated habitats by the avifauna of Southern Costa Rica. Ecol Appl 11:1-13. https://doi.org/10. 1890/1051-0761(2001)011[0001:CBUOHD]2.0.CO;2

de Matos DD, Ferreguetti ÁC, Rodrigues FHG (2020) Using an occupancy approach to identify poaching hotspots in protected areas in a seasonally dry tropical forest. Biol Conserv 251:108796. https://doi.org/10.1016/j.biocon.2020.108796

Devkota RS, Field R, Hoffmann S, et al (2020) Assessing the potential replacement of laurel forest by a novel ecosystem in the steep terrain of an Oceanic Island. Remote Sens 12:4013. https://doi.org/ $10.3390 / \mathrm{RS} 12244013$

Di Marco M, Collen B, Rondinini C, Mace GM (2015) Historical drivers of extinction risk: using past evidence to direct future monitoring. Proc R Soc B 282:20150928. https://doi.org/10.1098/rspb. 2015.0928

Di Marco M, Ferrier S, Harwood TD et al (2019) Wilderness areas halve the extinction risk of terrestrial biodiversity. Nature 573:582-585. https://doi.org/10.1038/s41586-019-1567-7 
Diagne C, Leroy B, Vaissière A-C et al (2021) High and rising economic costs of biological invasions worldwide. Nature. https://doi.org/10.1038/s41586-021-03405-6

Díaz S, Settele J, Brondízio ES et al (2019) Pervasive human-driven decline of life on Earth points to the need for transformative change. Science. https://doi.org/10.1126/science.aax3100

Díaz S, Zafra-Calvo N, Purvis A et al (2020) Set ambitious goals for biodiversity and sustainability. Science 370:411-413. https://doi.org/10.1126/science.abe1530

Dinerstein E, Vynne C, Sala E et al (2019) A global deal for nature: guiding principles, milestones, and targets. Sci Adv 5:eaaw2869. https://doi.org/10.1126/sciadv.aaw2869

Dinerstein E, Joshi AR, Vynne C et al (2020) A "Global Safety Net" to reverse biodiversity loss and stabilize Earth's climate. Sci Adv. https://doi.org/10.1126/sciadv.abb2824

Dobrovolski R, Loyola R, Fonseca DA, GAB, et al (2014) Globalizing conservation efforts to save species and enhance food production. Bioscience 64:539-545. https://doi.org/10.1093/biosci/biu064

Downey PO, Richardson DM (2016) Alien plant invasions and native plant extinctions: a six-threshold framework. AoB Plants. https://doi.org/10.1093/aobpla/plw047

Dudley N (2008) Guidelines for applying protected area management categories. IUCN, Gland

Dudley N, Jonas H, Nelson F et al (2018) The essential role of other effective area-based conservation measures in achieving big bold conservation targets. Glob Ecol Conserv 15:e00424. https://doi.org/10. 1016/j.gecco.2018.e00424

Dyer MI, Holland MM (1988) Unesco's man and the biosphere program. Bioscience 38:635-641. https:// doi.org/10.2307/1310830

Edwards DP, Laurance SG (2012) Green labelling, sustainability and the expansion of tropical agriculture: critical issues for certification schemes. Biol Conserv 151:60-64. https://doi.org/10.1016/j.biocon. 2012.01.017

Eldridge DJ, Bowker MA, Maestre FT, et al (2011) Impacts of shrub encroachment on ecosystem structure and functioning: Towards a global synthesis. Ecol. Lett.

Ellis EC (2019) To conserve nature in the anthropocene, half earth is not nearly enough. One Earth 1:163167. https://doi.org/10.1016/j.oneear.2019.10.009

Fahrig L (2017) Ecological responses to habitat fragmentation per se. Annu Rev Ecol Evol Syst 48:1-23. https://doi.org/10.1146/annurev-ecolsys-110316-022612

Feeley KJ, Silman MR (2010) Modelling the responses of Andean and Amazonian plant species to climate change: the effects of georeferencing errors and the importance of data filtering. J Biogeogr 37:733740. https://doi.org/10.1111/j.1365-2699.2009.02240.x

Felton A, Fischer J, Lindenmayer DB et al (2009) Climate change, conservation and management: an assessment of the peer-reviewed scientific journal literature. Biodivers Conserv 18:2243-2253. https://doi. org/10.1007/s10531-009-9652-0

Ferreira MT, Cardoso P, Borges PAV et al (2019) Implications of climate change to the design of protected areas: The case study of small islands (Azores). PLoS ONE 14:e0218168. https://doi.org/10.1371/ journal.pone.0218168

Foxcroft LC, Pyšek P, Richardson DM, Genovesi P (2013) Plant Invasions in protected areas. Springer, Netherlands

Foxcroft LC, Spear D, van Wilgen NJ, McGeoch MA (2019) Assessing the association between pathways of alien plant invaders and their impacts in protected areas. NeoBiota. https://doi.org/10.3897/NEOBI OTA.43.29644

Foxcroft LC, Richardson DM, Wilson JRU (2008) Ornamental plants as invasive aliens: problems and solutions in Kruger National Park, South Africa. Environ. Manag.

Fuentes-Castillo T, Scherson RA, Marquet PA et al (2019) Modelling the current and future biodiversity distribution in the Chilean Mediterranean hotspot. The role of protected areas network in a warmer future. Divers Distrib 25:1897-1909. https://doi.org/10.1111/ddi.12988

García-Barón I, Giakoumi S, Santos MB et al (2020) The value of time-series data for conservation planning. J Appl Ecol 1365-2664:13790. https://doi.org/10.1111/1365-2664.13790

García-Frapolli E, Ramos-Fernández G, Galicia E, Serrano A (2009) The complex reality of biodiversity conservation through Natural Protected Area policy: three cases from the Yucatan Peninsula, Mexico. Land Use Policy 26:715-722. https://doi.org/10.1016/j.landusepol.2008.09.008

Gavin MC, McCarter J, Mead A et al (2015) Defining biocultural approaches to conservation. Trends Ecol Evol 30:140-145. https://doi.org/10.1016/j.tree.2014.12.005

Gavin MC, McCarter J, Berkes F et al (2018) Effective biodiversity conservation requires dynamic, pluralistic. Partnership-based approaches. Sustainability 10:1846. https://doi.org/10.3390/su10061846

Geldmann J, Barnes M, Coad L et al (2013) Effectiveness of terrestrial protected areas in reducing habitat loss and population declines. Biol Conserv 161:230-238. https://doi.org/10.1016/j.biocon.2013.02. 018 
Geldmann J, Coad L, Barnes MD et al (2018) A global analysis of management capacity and ecological outcomes in terrestrial protected areas. Conserv Lett 11:e12434. https://doi.org/10.1111/conl.12434

Geldmann J, Manica A, Burgess ND et al (2019) A global-level assessment of the effectiveness of protected areas at resisting anthropogenic pressures. Proc Natl Acad Sci 116:23209-23215. https://doi.org/10. 1073/pnas.1908221116

Gibson L, Lynam AJ, Bradshaw CJA et al (2013) Near-complete extinction of native small mammal fauna 25 years after forest fragmentation. Science 341:1508-1510. https://doi.org/10.1126/science.1240495

Gillespie TW, Willis KS, Ostermann-Kelm S (2015) Spaceborne remote sensing of the world's protected areas. Prog Phys Geogr Earth Environ 39:388-404. https://doi.org/10.1177/0309133314561648

Gillson L, Dawson TP, Jack S, McGeoch MA (2013) Accommodating climate change contingencies in conservation strategy. Trends Ecol Evol 28:135-142. https://doi.org/10.1016/j.tree.2012.10.008

Gillson L, Biggs H, Smit IPJ et al (2019) Finding common ground between adaptive management and evidence-based approaches to biodiversity conservation. Trends Ecol Evol 34:31-44. https://doi.org/10. 1016/j.tree.2018.10.003

Gray CL, Hill SLL, Newbold T et al (2016) Local biodiversity is higher inside than outside terrestrial protected areas worldwide. Nat Commun 7:12306. https://doi.org/10.1038/ncomms 12306

Gross JE, Woodley S, Welling LA, Watson JEM (2017) Adapting to climate change: guidance for protected area managers and planners. IUCN, Gland

Haase P, Tonkin JD, Stoll S et al (2018) The next generation of site-based long-term ecological monitoring: linking essential biodiversity variables and ecosystem integrity. Sci Total Environ 613-614:13761384. https://doi.org/10.1016/j.scitotenv.2017.08.111

Hagerman SM, Satterfield T (2014) Agreed but not preferred: expert views on taboo options for biodiversity conservation, given climate change. Ecol Appl 24:548-559. https://doi.org/10.1890/13-0400.1

Hajjar R, Oldekop JA, Cronkleton P et al (2021) A global analysis of the social and environmental outcomes of community forests. Nat Sustain 4:216-224. https://doi.org/10.1038/s41893-020-00633-y

Hallegatte S (2009) Strategies to adapt to an uncertain climate change. Glob Environ Chang 19:240-247. https://doi.org/10.1016/j.gloenvcha.2008.12.003

Hamilton A, Cunningham A, Byarugaba D, Kayanja F (2000) Conservation in a region of political instability: Bwindi impenetrable forest, Uganda. Conserv Biol 14:1722-1725. https://doi.org/10.1046/j.15231739.2000.99452.x

Hannah L, Midgley GF, Millar D (2002) Climate change-integrated conservation strategies. Glob Ecol Biogeogr 11:485-495. https://doi.org/10.1046/j.1466-822X.2002.00306.X

Hanspach J, Jamila Haider L, Oteros-Rozas E et al (2020) Biocultural approaches to sustainability: a systematic review of the scientific literature. People Nat 2:643-659. https://doi.org/10.1002/pan3.10120

Hellwig N, Walz A, Markovic D (2019) Climatic and socioeconomic effects on land cover changes across Europe: does protected area designation matter? PLoS ONE 14:e0219374. https://doi.org/10.1371/ journal.pone.0219374

Hemp A (2008) Introduced plants on Kilimanjaro: tourism and its impact. Plant Ecol. https://doi.org/10. 1007/s11258-007-9356-Z

Hendricks SA, Sesink Clee PR, Harrigan RJ et al (2016) Re-defining historical geographic range in species with sparse records: implications for the Mexican wolf reintroduction program. Biol Conserv 194:48-57. https://doi.org/10.1016/j.biocon.2015.11.027

Hickey V, Pimm SL (2011) How the World Bank funds protected areas. Conserv Lett 4:269-277. https:// doi.org/10.1111/j.1755-263X.2011.00172.x

Hillebrand H, Blasius B, Borer ET et al (2018) Biodiversity change is uncoupled from species richness trends: consequences for conservation and monitoring. J Appl Ecol 55:169-184. https://doi.org/10. $1111 / 1365-2664.12959$

Hockings M, Stolton S, Leverington F et al (2006) Evaluating effectiveness: a framework for assessing management effectiveness of protected areas, 2nd edn. IUCN, Gland

Hoffmann S (2021) Advances in conservation biogeography: towards protected area effectiveness under anthropogenic threats. Front Biogeogr. https://doi.org/10.21425/F5FBG49679

Hoffmann S, Beierkuhnlein C (2020) Climate change exposure and vulnerability of the global protected area estate from an international perspective. Divers Distrib. https://doi.org/10.1111/ddi.13136

Hoffmann S, Irl SDH, Beierkuhnlein C (2019a) Predicted climate shifts within terrestrial protected areas worldwide. Nat Commun 10:4787. https://doi.org/10.1038/s41467-019-12603-w

Hoffmann S, Schmitt TM, Chiarucci A et al (2019b) Remote sensing of $\beta$-diversity: evidence from plant communities in a semi-natural system. Appl Veg Sci 22:13-26. https://doi.org/10.1111/avsc.12403

Hoffmann S, Steiner L, Schweiger AH et al (2019c) Optimizing sampling effort and information content of biodiversity surveys: a case study of alpine grassland. Ecol Inform 51:112-120. https://doi.org/10. 1016/J.ECOINF.2019.03.003 
Holl KD (2017) Restoring tropical forests from the bottom up. Science

Holsinger L, Parks SA, Parisien M et al (2019) Climate change likely to reshape vegetation in North America's largest protected areas. Conserv Sci Pract 1:e50. https://doi.org/10.1111/csp2.50

Horning N, Robinson J, Sterling EJ et al (2010) Remote sensing for ecology and conservation. Oxford University Press, Oxford

Hortal J, de Bello F, Diniz-Filho JAF et al (2015) Seven shortfalls that beset large-scale knowledge of biodiversity. Annu Rev Ecol Evol Syst 46:523-549. https://doi.org/10.1146/annurev-ecols ys-112414-054400

IPBES (2019) Summary for policymakers of the global assessment report on biodiversity and ecosystem services of the Intergovernmental Science-Policy Platform on Biodiversity and Ecosystem Services. IPBES, Bonn

IUCN, UNEP-WCMC (2021) The World Database on Protected Areas. www.protectedplanet.net. Accessed 1 Apr 2021

IUCN, WCPA, ASI (2019) IUCN Green List of Protected and Conserved Areas: User Manual, Version 1.2. Gland

Jackson SF, Gaston KJ (2008) Land use change and the dependence of national priority species on protected areas. Glob Chang Biol 14:2132-2138. https://doi.org/10.1111/j.1365-2486.2008.01628.x

Jacquemyn H, Van MC, Brys R, Honnay O (2011) Management effects on the vegetation and soil seed bank of calcareous grasslands: an 11-year experiment. Biol Conserv. https://doi.org/10.1016/j.biocon.2010. 09.020

Jones KR, Venter O, Fuller RA et al (2018) One-third of global protected land is under intense human pressure. Science 360:788-791. https://doi.org/10.1126/science.aap9565

Joppa LN, Pfaff A (2009) High and far: biases in the location of protected areas. PLoS ONE 4:e8273. https://doi.org/10.1371/journal.pone.0008273

Joppa LN, Loarie SR, Pimm SL (2008) On the protection of "protected areas." Proc Natl Acad Sci 105:6673-6678. https://doi.org/10.1073/pnas.0802471105

Joppa LN, Visconti P, Jenkins CN, Pimm SL (2013) Achieving the convention on biological diversity's goals for plant conservation. Science 341:1100-1103. https://doi.org/10.1126/science.1241706

JRC (2021) Digital observatory for protected areas. https://dopa-explorer.jrc.ec.europa.eu/dopa_explorer. Accessed 1 Apr 2021

Keeton WS, Kraft CE, Warren DR (2007) Mature and old-growth riparian forests: structure, dynamics, and effects on adirondack stream habitats. Ecol Appl. https://doi.org/10.1890/06-1172

Kendle AD, Rose JE (2000) The aliens have landed! what are the justifications for 'native only' policies in landscape plantings? Landsc Urban Plan 47:19-31. https://doi.org/10.1016/S0169-2046(99)00070-5

Kintisch E (2013) Climate study highlights wedge issue. Science 339:128-129. https://doi.org/10.1126/ science.339.6116.128

Kissling WD, Hardisty A, García EA et al (2015) Towards global interoperability for supporting biodiversity research on essential biodiversity variables (EBVs). Biodiversity 16:99-107. https://doi.org/10. 1080/14888386.2015.1068709

Kreyling J, Bittner T, Jaeschke A et al (2011) Assisted colonization: a question of focal units and recipient localities. Restor Ecol 19:433-440. https://doi.org/10.1111/j.1526-100X.2011.00777.x

Kroner REG, Qin S, Cook CN et al (2019) The uncertain future of protected lands and waters. Science 364:881-886. https://doi.org/10.1126/science.aau5525

Ladle RJ, Jepson P, Gillson L (2011) Social values and conservation biogeography. In: Ladle RJ, Whittaker RJ (eds) conservation biogeography. Wiley, Chichester

Lamba A, Cassey P, Segaran RR, Koh LP (2019) Deep learning for environmental conservation. Curr Biol 29:R977-R982. https://doi.org/10.1016/j.cub.2019.08.016

Larson AJ, Belote RT, Williamson MA, Aplet GH (2013) Making monitoring count: project design for active adaptive management. J for 111:348-356. https://doi.org/10.5849/jof.13-021

Lawrence A, Hoffmann S, Beierkuhnlein C (2021) Topographic diversity as an indicator for resilience of terrestrial protected areas against climate change. Glob Ecol Conserv 25:e01445. https://doi.org/10. 1016/j.gecco.2020.e01445

Lehikoinen P, Santangeli A, Jaatinen K et al (2019) Protected areas act as a buffer against detrimental effects of climate change-evidence from large-scale, long-term abundance data. Glob Chang Biol 25:304313. https://doi.org/10.1111/gcb.14461

Leverington F, Costa KL, Pavese $\mathrm{H}$ et al (2010) A global analysis of protected area management effectiveness. Environ Manag 46:685-698. https://doi.org/10.1007/s00267-010-9564-5

Liu X, Blackburn TM, Song T et al (2020) Animal invaders threaten protected areas worldwide. Nat Commun 11:2892. https://doi.org/10.1038/s41467-020-16719-2 
Margules CR, Pressey RL (2000) Systematic conservation planning. Nature 405:243-253. https://doi.org/ $10.1038 / 35012251$

Margules CR, Pressey RL, Williams PH (2002) Representing biodiversity: data and procedures for identifying priority areas for conservation. J Biosci 27:309-326. https://doi.org/10.1007/BF02704962

Margules C, Boedhihartono AK, Langston JD et al (2020) Transdisciplinary science for improved conservation outcomes. Environ Conserv 47:224-233. https://doi.org/10.1017/S0376892920000338

Maron M, Rhodes JR, Gibbons P (2013) Calculating the benefit of conservation actions. Conserv Lett 6:359-367. https://doi.org/10.1111/conl.12007

Mascia MB, Pailler S (2011) Protected area downgrading, downsizing, and degazettement (PADDD) and its conservation implications. Conserv Lett 4:9-20. https://doi.org/10.1111/j.1755-263X.2010.00147.x

Mascia MB, Pailler S, Thieme ML et al (2014) Commonalities and complementarities among approaches to conservation monitoring and evaluation. Biol Conserv 169:258-267. https://doi.org/10.1016/j.biocon. 2013.11.017

Maxwell SL, Cazalis V, Dudley N et al (2020) Area-based conservation in the twenty-first century. Nature 586:217-227. https://doi.org/10.1038/s41586-020-2773-Z

Mayer C (2019) Valuing the invaluable: how much is the planet worth? Oxford Rev Econ Policy 35:109119. https://doi.org/10.1093/oxrep/gry024

McCarthy DP, Donald PF, Scharlemann JPW et al (2012) Financial costs of meeting global biodiversity conservation targets: current spending and unmet needs. Science 338:946-949. https://doi.org/10. 1126/science. 1229803

McKinley DC, Miller-Rushing AJ, Ballard HL et al (2017) Citizen science can improve conservation science, natural resource management, and environmental protection. Biol Conserv 208:15-28. https:// doi.org/10.1016/j.biocon.2016.05.015

Merckx T, Pereira HM (2015) Reshaping agri-environmental subsidies: from marginal farming to largescale rewilding. Basic Appl Ecol 16:95-103. https://doi.org/10.1016/j.baae.2014.12.003

Michalak JL, Withey JC, Lawler JJ, Case MJ (2017) Future climate vulnerability-evaluating multiple lines of evidence. Front Ecol Environ 15:367-376. https://doi.org/10.1002/fee.1516

Miller DC (2014) Explaining global patterns of international aid for linked biodiversity conservation and development. World Dev. https://doi.org/10.1016/j.worlddev.2014.01.004

Minteer BA, Miller TR (2011) The new conservation debate: ethical foundations, strategic trade-offs, and policy opportunities. Biol Conserv 144:945-947. https://doi.org/10.1016/j.biocon.2010.07.027

Moilanen A, Wilson KA, Possingham HP (2009) Spatial conservation prioritization: quantitative methods and computational tools. Oxford University Press, Oxford

Montesino Pouzols F, Toivonen T, Di Minin E et al (2014) Global protected area expansion is compromised by projected land-use and parochialism. Nature 516:383-386. https://doi.org/10.1038/nature 14032

Moreno-Mateos D, Maris V, Béchet A, Curran M (2015) The true loss caused by biodiversity offsets. Biol Conserv 192:552-559. https://doi.org/10.1016/j.biocon.2015.08.016

Murcia C (1995) Edge effects in fragmented forests: implications for conservation. Trends Ecol Evol 10:5862. https://doi.org/10.1016/S0169-5347(00)88977-6

Myers N (1998) Lifting the veil on perverse subsidies. Nature 392:327-328. https://doi.org/10.1038/32761

Naughton-Treves L, Holland MB, Brandon K (2005) The role of protected areas in conserving biodiversity and sustaining local livelihoods. Annu Rev Environ Resour 30:219-252. https://doi.org/10.1146/ annurev.energy.30.050504.164507

Nimmo DG, Kelly LT, Spence-Bailey LM et al (2013) Fire mosaics and reptile conservation in a fire-prone region. Conserv Biol. https://doi.org/10.1111/j.1523-1739.2012.01958.x

Oldekop JA, Holmes G, Harris WE, Evans KL (2016) A global assessment of the social and conservation outcomes of protected areas. Conserv Biol 30:133-141. https://doi.org/10.1111/cobi.12568

Olden JD, LeRoy PN, Douglas MR et al (2004) Ecological and evolutionary consequences of biotic homogenization. Trends Ecol Evol 19:18-24. https://doi.org/10.1016/j.tree.2003.09.010

Olden JD, Kennard MJ, Lawler JJ, Poff NJ (2011) Challenges and opportunities in implementing managed relocation for conservation of freshwater species. Conserv Biol 25:40-47. https://doi.org/10.1111/j. 1523-1739.2010.01557.x

Ondei S, Brook BW, Buettel JC (2018) Nature's untold stories: an overview on the availability and type of on-line data on long-term biodiversity monitoring. Biodivers Conserv 27:2971-2987. https://doi.org/ $10.1007 / \mathrm{s} 10531-018-1582-2$

Paknia O, Rajaei ShH, Koch A (2015) Lack of well-maintained natural history collections and taxonomists in megadiverse developing countries hampers global biodiversity exploration. Org Divers Evol. https://doi.org/10.1007/s13127-015-0202-1

Pereira HM, Ferrier S, Walters M et al (2013) Essential biodiversity variables. Science 339:277-278. https:// doi.org/10.1126/science. 1229931 
Perrings C, Dehnen-Schmutz K, Touza J, Williamson M (2005) How to manage biological invasions under globalization. Trends Ecol Evol 20:212-215. https://doi.org/10.1016/j.tree.2005.02.011

Peters RL, Darling JDS (1985) The greenhouse effect and nature reserves. Bioscience 35:707-717. https:// doi.org/10.2307/1310052

Pimm SL, Jenkins CN, Li BV (2018) How to protect half of Earth to ensure it protects sufficient biodiversity. Sci Adv. https://doi.org/10.1126/sciadv.aat2616

Polasky S, Carpenter SR, Folke C, Keeler B (2011) Decision-making under great uncertainty: environmental management in an era of global change. Trends Ecol Evol 26:398-404. https://doi.org/10.1016/j. tree.2011.04.007

Porensky LM, Young TP (2013) Edge-effect interactions in fragmented and patchy landscapes. Conserv Biol 27:509-519. https://doi.org/10.1111/cobi.12042

Primack RB, Sher A (2016) Introduction to conservation biology. Sinauer Associates Inc, Sunderland

Rands MRW, Adams WM, Bennun L et al (2010) Biodiversity conservation: challenges beyond 2010. Science 329:1298-1303. https://doi.org/10.1126/science.1189138

Redpath SM, Young J, Evely A, et al (2013) Understanding and managing conservation conflicts. Trends Ecol Evol

Reed J, Oldekop J, Barlow J et al (2020) The extent and distribution of joint conservation-development funding in the tropics. One Earth 3:753-762. https://doi.org/10.1016/j.oneear.2020.11.008

Reyers B, Stafford-Smith M, Erb K-H et al (2017) Essential variables help to focus sustainable development goals monitoring. Curr Opin Environ Sustain 26-27:97-105. https://doi.org/10.1016/j. cosust.2017.05.003

Rist L, Campbell BM, Frost P (2013) Adaptive management: where are we now? Environ Conserv 40:518. https://doi.org/10.1017/S0376892912000240

Rocchini D, Marcantonio M, Da Re D et al (2019) Time-lapsing biodiversity: an open source method for measuring diversity changes by remote sensing. Remote Sens Environ 231:111192. https://doi.org/ 10.1016/j.rse.2019.05.011

Rodrigues ASL, Cazalis V (2020) The multifaceted challenge of evaluating protected area effectiveness. Nat Commun 11:5147. https://doi.org/10.1038/s41467-020-18989-2

Roe D, Mohammed EY, Porras I, Giuliani A (2013) Linking biodiversity conservation and poverty reduction: de-polarizing the conservation-poverty debate. Conserv Lett 6:162-171. https://doi.org/ 10.1111/j.1755-263X.2012.00292.x

Rose RA, Byler D, Eastman JR et al (2015) Ten ways remote sensing can contribute to conservation. Conserv Biol 29:350-359. https://doi.org/10.1111/cobi.12397

Runting RK, Phinn S, Xie Z et al (2020) Opportunities for big data in conservation and sustainability. Nat Commun 11:2003. https://doi.org/10.1038/s41467-020-15870-0

Sanderson EW, Jaiteh M, Levy MA et al (2002) The human footprint and the last of the wild. Bioscience 52:891-904. https://doi.org/10.1641/0006-3568(2002)052[0891:thfat1]2.0.co;2

Sarkar S, Illoldi-Rangel P (2010) Systematic conservation planning: an updated protocol. Nat Conserv 08:19-26. https://doi.org/10.4322/natcon.00801003

Saura S, Bertzky B, Bastin L et al (2018) Protected area connectivity: shortfalls in global targets and country-level priorities. Biol Conserv 219:53-67. https://doi.org/10.1016/j.biocon.2017.12.020

Scheffer M, Barrett S, Carpenter SR et al (2015) Creating a safe operating space for iconic ecosystems. Science 347:1317-1319. https://doi.org/10.1126/science.aaa3769

Scheiter S, Higgins SI (2012) How many elephants can you fit into a conservation area. Conserv Lett 5:176-185. https://doi.org/10.1111/j.1755-263X.2012.00225.X

Schmidt K, Martín-López B, Phillips PM et al (2019) Key landscape features in the provision of ecosystem services: Insights for management. Land Use Policy 82:353-366. https://doi.org/10.1016/j. landusepol.2018.12.022

Schrodt F, Bailey JJ, Kissling WD et al (2019) Opinion: to advance sustainable stewardship, we must document not only biodiversity but geodiversity. Proc Natl Acad Sci 116:16155-16158. https:// doi.org/10.1073/pnas.1911799116

Schulze K, Knights K, Coad L et al (2018) An assessment of threats to terrestrial protected areas. Conserv Lett 11:e12435. https://doi.org/10.1111/conl.12435

Serra-Diaz JM, Franklin J (2019) What's hot in conservation biogeography in a changing climate? Going beyond species range dynamics. Divers Distrib 25:492-498. https://doi.org/10.1111/ddi.12917

Shackelford N, Hobbs RJ, Heller NE et al (2013) Finding a middle-ground: the native/non-native debate. Biol Conserv 158:55-62. https://doi.org/10.1016/j.biocon.2012.08.020

Shackleton RT, Shackleton CM, Kull CA (2019) The role of invasive alien species in shaping local livelihoods and human well-being: a review. J Environ Manag. https://doi.org/10.1016/j.jenvman. 2018.05.007 
Silvério DV, Brando PM, Macedo MN et al (2015) Agricultural expansion dominates climate changes in southeastern Amazonia: the overlooked non-GHG forcing. Environ Res Lett 10:104015. https:// doi.org/10.1088/1748-9326/10/10/104015

Soares-Filho B, Moutinho P, Nepstad D et al (2010) Role of Brazilian Amazon protected areas in climate change mitigation. Proc Natl Acad Sci 107:10821-10826. https://doi.org/10.1073/pnas. 0913048107

Socolar JB, Gilroy JJ, Kunin WE, Edwards DP (2016) How should beta-diversity inform biodiversity conservation? Trends Ecol Evol 31:67-80. https://doi.org/10.1016/j.tree.2015.11.005

Stein BA, Kuttner LS, Adams JS (2000) Precious heritage: the status of biodiversity in the United States. Oxford University Press, New York

Strassburg BBN, Iribarrem A, Beyer HL et al (2020) Global priority areas for ecosystem restoration. Nature 586:724-729. https://doi.org/10.1038/s41586-020-2784-9

Svenning J-C, Pedersen PBM, Donlan CJ et al (2016) Science for a wilder Anthropocene: synthesis and future directions for trophic rewilding research. Proc Natl Acad Sci 113:898-906. https://doi.org/ 10.1073/pnas.1502556112

Thomas CD, Gillingham PK (2015) The performance of protected areas for biodiversity under climate change. Biol J Linn Soc 115:718-730. https://doi.org/10.1111/bij.12510

Tilman D, Clark M, Williams DR et al (2017) Future threats to biodiversity and pathways to their prevention. Nature 546:73-81. https://doi.org/10.1038/nature22900

Toral-Granda MV, Causton CE, Jäger H et al (2017) Alien species pathways to the Galapagos Islands. Ecuador Plos One 12:e0184379. https://doi.org/10.1371/journal.pone.0184379

Tucker MA, Böhning-Gaese K, Fagan WF et al (2018) Moving in the anthropocene: global reductions in terrestrial mammalian movements. Science 359:466-469. https://doi.org/10.1126/science.aam97 12

United Nations (2015) THE 17 GOALSIsustainable development. https://sdgs.un.org/goals. Accessed 1 Jul 2021

Venevsky S, Venevskaia I (2005) Hierarchical systematic conservation planning at the national level: identifying national biodiversity hotspots using abiotic factors in Russia. Biol Conserv 124:235251. https://doi.org/10.1016/j.biocon.2005.01.036

Vieira RRS, Pressey RL, Loyola R (2019) The residual nature of protected areas in Brazil. Biol Conserv 233:152-161. https://doi.org/10.1016/j.biocon.2019.02.010

Visconti P, Butchart SHM, Brooks TM et al (2019) Protected area targets post-2020. Science 364:eaav6886. https://doi.org/10.1126/science.aav6886

Waldron A, Miller DC, Redding D et al (2017) Reductions in global biodiversity loss predicted from conservation spending. Nature 551:364-367. https://doi.org/10.1038/nature24295

Ward M, Saura S, Williams B et al (2020) Just ten percent of the global terrestrial protected area network is structurally connected via intact land. Nat Commun 11:4563. https://doi.org/10.1038/ s41467-020-18457-x

Watson JEM, Iwamura T, Butt N (2013) Mapping vulnerability and conservation adaptation strategies under climate change. Nat Clim Chang 3:989-994. https://doi.org/10.1038/nclimate2007

Watson JEM, Dudley N, Segan DB, Hockings M (2014) The performance and potential of protected areas. Nature 515:67-73. https://doi.org/10.1038/nature13947

Watson JEM, Darling ES, Venter O et al (2016) Bolder science needed now for protected areas. Conserv Biol 30:243-248. https://doi.org/10.1111/cobi.12645

Wcpa IUCN (2019) Recognising and reporting other effective area-based conservation measures. IUCN, Gland

Wegmann M, Santini L, Leutner B et al (2014) Role of African protected areas in maintaining connectivity for large mammals. Philos Trans R Soc B 369:20130193. https://doi.org/10.1098/rstb.2013. 0193

Whittaker RJ, Araújo MB, Jepson P et al (2005) Conservation Biogeography: assessment and prospect. Divers Distrib 11:3-23. https://doi.org/10.1111/j.1366-9516.2005.00143.x

Wiersma YF, Nudds TD, Rivard DH (2004) Models to distinguish effects of landscape patterns and human population pressures associated with species loss in Canadian national parks. Landsc Ecol 19:773-786. https://doi.org/10.1007/s10980-005-3989-y

Wilcove DS, Master LL (2005) How many endangered species are there in the United States? Front Ecol Environ 3:414-420. https://doi.org/10.1890/1540-9295(2005)003[0414:HMESAT]2.0.CO;2

Williams BK (2011) Adaptive management of natural resources-framework and issues. J Environ Manag 92:1346-1353. https://doi.org/10.1016/j.jenvman.2010.10.041 
Wilson HB, Meijaard E, Venter O et al (2014) Conservation strategies for orangutans: reintroduction versus habitat preservation and the benefits of sustainably logged forest. PLoS ONE 9:e102174. https://doi.org/10.1371/journal.pone.0102174

Wilson MC, Chen X-Y, Corlett RT et al (2016) Habitat fragmentation and biodiversity conservation: key findings and future challenges. Landsc Ecol 31:219-227. https://doi.org/10.1007/ s10980-015-0312-3

Wintle BA, Bekessy SA, Keith DA et al (2011) Ecological-economic optimization of biodiversity conservation under climate change. Nat Clim Chang 1:355-359. https://doi.org/10.1038/nclimate1227

Wintle BA, Kujala H, Whitehead A et al (2019) Global synthesis of conservation studies reveals the importance of small habitat patches for biodiversity. Proc Natl Acad Sci 116:909-914. https://doi. org/10.1073/pnas.1813051115

Worboys GL, Lockwood M, Kothari A et al (2015) Protected area governance and management. ANU Press, Gland

Wüest RO, Zimmermann NE, Zurell D et al (2019) Macroecology in the age of big data—where to go from here? J Biogeogr 00:1-12. https://doi.org/10.1111/jbi.13633

$\mathrm{Xu} \mathrm{W,} \mathrm{Xiao} \mathrm{Y,} \mathrm{Zhang} \mathrm{J} \mathrm{et} \mathrm{al} \mathrm{(2017)} \mathrm{Strengthening} \mathrm{protected} \mathrm{areas} \mathrm{for} \mathrm{biodiversity} \mathrm{and} \mathrm{ecosystem} \mathrm{ser-}$ vices in China. Proc Natl Acad Sci 114:1601-1606. https://doi.org/10.1073/pnas.1620503114

Zafra-Calvo N, Garmendia E, Pascual U et al (2019) Progress toward equitably managed protected areas in Aichi target 11: a global survey. Bioscience 69:191-197. https://doi.org/10.1093/biosci/biy143

Zaradic PA, Pergams ORW, Kareiva P (2009) The impact of nature experience on willingness to support conservation. PLoS ONE 4:e7367. https://doi.org/10.1371/journal.pone.0007367

Publisher's Note Springer Nature remains neutral with regard to jurisdictional claims in published maps and institutional affiliations. 